\title{
PREFACE
}

\section{Setting the Record Straight}

FRIEND of mine recently installed solar panels on her
workplace in New York City. This is no small feat.
Most buildings in New York are surrounded by even taller buildings which block sunlight for much of the day. But the roof of my friend's building is clear, so she contracted a local company to install the solar panels.

A few months later I had the opportunity to visit, along with several other friends. We all looked at the solar panels on the roof. One friend expressed astonishment that the panels could generate enough electricity to supply the entire building. Another worried that they would be a poor investment. A third friend maintained that solar would always need government subsidies to be financially viable for consumers. They are all smart and highly educated, but they were wrong on every point.

From this experience I began to ask myself: Why do so many people know so little about renewable energy? The rapid growth in renewable wind and solar is not a secret. Towering wind turbines and shimmering solar panels are hard to miss. Yet most people are woefully unaware of what is happening in the energy sector. Bill Ritter, the former governor of Colorado, identified the source of the problem: "People have misconceptions about the 
cost of renewable energy largely because the public conversation about these resources has been in the form of TV campaign ads and campaign debates, where the truth is, at best, elusive."1

Misinformation from politicians has obscured a remarkable energy transition by which renewables have become cost competitive with fossil fuels. And the rise of renewables is only half the story. The transportation sector is also undergoing a transition, from gasoline- and diesel-powered vehicles to electric vehicles. Energy and transportation, two of the world's largest and most valuable industries, are entering a period of dramatic and interlinked change.

As a business school professor, I find these changes interesting. Much of the material in this book stems from the classes I teach at Columbia Business School, but I have more than an academic interest in renewable energy. I am also an investor in early-stage companies. Like many investors, I focus on long-term trends, such as the changes occurring in the energy and transportation sectors. While the timing of the transition to renewable energy and electric vehicles is challenging to predict, the overall trends are clear, creating exciting opportunities for investment.

This brings me to why I have written this book: so that everyone-my friends included - might understand the energy transition to renewables already underway: to set the record straight. Awareness of this trend matters because how we produce and consume energy is critical to our way of life and to the future of our planet. We all need to be making smart decisions about energy. We need our politicians and governments to do so as well. I hope this short book helps in that regard.

My thanks to Patrick Fitzgerald and Brian Smith of Columbia University Press for embracing a first-time author. Special thanks 


\section{Preface ix}

to Steph Shaw for her exceptional research and editing, and to Michael Gerrard, Dave Kirkpatrick, and Charlie Donovan for taking the time to review and provide feedback. To my brother, Eric Usher, thank you for leading me into this sector in the first place. Naomi, Ben, and Theo, thank you for supporting my career switch to academia. And to my students at Columbia Business School, thank you for motivating and challenging me every day. 



\section{RENEWABLE ENERGY}




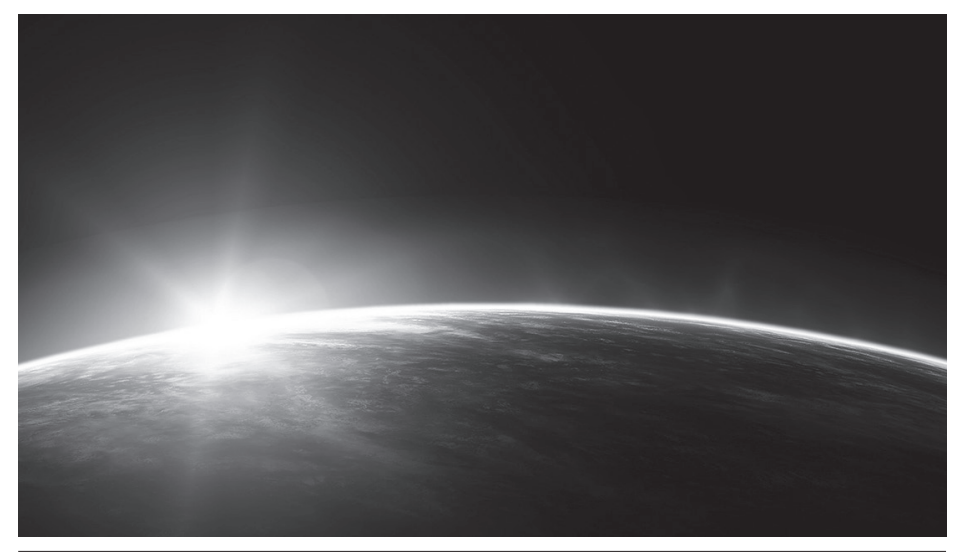

FIGURE 1.1 The Earth. (Source: http://deskbg.com/) 